\title{
POLA PENGASUHAN ANAK DAN PROSES INTERNALISASI NILAI BUDAYA BERBASIS AJARAN ISLAM DI KAMPUNG JAWA-TONDANO
}

\section{CHILD CARE PATTERNS AND INTERNALIZATION PROCESSES BASED ON ISLAMIC VALUES IN JAWA TONDANO VILLAGE}

\author{
Salmin Djakaria \\ Balai Pelestarian Nilai Budaya Manado \\ Jl. Katamso, Bumi Beringin, Ling. V. Manado \\ Email: salmin_dj@yahoo.com
}

Naskah diterima tanggal 5 Februari 2018. Naskah direvisi tanggal 22 Februari 2018. Naskah disetujui tanggal 18 Mei 2018

\begin{abstract}
Abstrak
Artikel ini bertujuan mendeskripsikan model-model internalisasi nilai budaya berbasis ajaran agama Islam yang terjadi pada masyarakat kampung Jawa-Tondano (Jaton) di Minahasa dan bagaimana hal tersebut berperan dalam proses pembentukan karakter warganya. Artikel ini juga akan menunjukkan bagaimana nilai dalam proses intenalisasi berperan pada pembentukan karakter warga. Internalisasi nilai ini dilakukan terutama lewat seni tutur, yaitu dengan menyenandungkan: Salawat, pantun, ungkapanungkapan dan nasihat. Seni tutur sebagaimana yang dijelaskan dalam artikel ini tidak hanya bermanfaat dalam menginternalisasi nilai-nilai Islami, tetapi juga menjadi salah satu faktor pembentuk karakter orang Jaton, sebagai salah entitas komunitas yang spesifik. Disamping itu, seni tutur yang dimaksud juga membentuk sebuah identitas yang memperkuat ikatan mereka sebagai orang Jaton, sehingga sekalipun bermukim di wilayah-wilayah diaspora, namun ikatan dengan kampung halamannya tetap terjaga baik dalam artian familial, personal dan sosial. Artikel ini didasarkan pada penelitian lapangan dengan menggunakan metode kualitatif yang teknik pengumpulan datanya terutama lewat wawancara, observasi, dan lewat Focus Group Discussion (FGD) yang difokuskan pada pendekatan pengalaman individu.
\end{abstract}

Kata kunci: Islam, Jaton, Salawat, Pantun, Nasihat, Internalisasi, Nilai

\begin{abstract}
This article aims to describe the forms of culture-value internalization processes, based on the value of Islam which is happened in the society of Kampung Jawa-Tondano (Jaton), the regency of Minahasa. This article also will show how that value within the internalization processes taken a role in the character building. Forms of this processes include Salawat, poem, idioms, and advice. Art of spelling as described in this article not only useful to internalize Islamic values but also as one of the primary factors to build their character as People of Jaton as a specific group of community. Besides, the art of spelling as mentioned also forming an identity which strengthens their ties as people of Jaton, even they have been living outside of the village or in diasporas area, connection to their homeland still maintained. This article based on field research were using the qualitative methodology and the collecting data mainly used interview, observation and Focus Group Discussion (FGD) which had been a focus to life history approach.
\end{abstract}

Keywords: Islam, Jaton, Internalization, Value

\section{PENDAHULUAN}

$\mathrm{I}$ nternalisional merupakan salah satu konsep paling mendasar dalam Antropologi, yaitu terjadi pada proses belajar dan mengenal kebudayaan sendiri yang sebenarnya telah dimulai sejak masih bayi. Para antropolog mengidentifikasi proses ini dalam tiga konsep dasar yaitu internalisasi, sosialisasi, dan enkulturasi (Koentjaraningrat, 2009:
185-191). Ada proses internalisasi yang tersistem seperti pelatihan atau lebih tepat pembiasaanpembiasaan, mulai dari menyusui, cara melatih disiplin makan, sopan-santun dalam berinteraksi dan sebagainya. Ada pula yang tak tersistem seperti melihat kebiasaan-kebiasaan individu di sekitarnya, mendengar ucapan-ucapan, lagu-lagu, dongeng, serta kisah-kisah kesejarahan lainnya. Khusus tentang ucapan atau ungkapan maupun lagu- 
lagu yang biasanya dinyanyikan untuk meninabobokan anak bayi; setiap daerah mempunyai istilah masing-masing misalnya pada masyarakat Gorontalo dikenal tradisi dan sastra lisan yang disebut Tinilo Mopotuluhu Banta (Djakaria, 2012: 41-45) yang artinya syair yang dilantunkan pada saat menidurkan anak.

Hal serupa juga dapat ditemukan di kalangan warga masyarakat kampung Jawa Tondano. Hal itu juga pernah dikemukakan oleh Timothy G. Babcock, seorang antropolog asal Kanada yang menulis disertasi tentang Kampung Jawa Tondano. Bukunya Kampung Jawa Tondano, Religion and Cultural Identity mengisyaratkan betapa unsur agama merupakan penanda identitas Orang Jawa Tondano. Salah satu unsur budaya-agama Islam yang sering digunakan untuk menginternalisasi nilai ketika mereka menggendong atau menina-bobokan bayi adalah lewat "Salawat", yang bukan sekadar lagu, melainkan juga dendangan doa permohonan. Karena itu, tulisan ini akan mendeskripsikan proses internalisasi nilai budaya berbasis ajaran Islam pada masyarakat Kampung Jawa Tondano, yaitu lewat Salawat, pantun dan nasihat-nasihat.

Artikel ini mengangkat rumusan masalah berupa deskripsi pola pengasuhan anak berbasis nilai-nilai Islam dan budaya lokal yang dilakukan oleh masyarakat Kampung Jawa Tondano. Dalam hal ini, tujuan dari pola pengasuhan anak tersebut tidak hanya membentuk karakter yang berbasis nilai budaya Islam, tetapi juga berfungsi mengikat anggota masyarakatnya secara psikologis dalam identitas kultural spesifik yaitu sebagai orang Jaton. Melekatkan persaudaraan sekalipun merantau atau berada dalam wilayah-wilayah diaspora.

Pada pihak lain, manfaat secara akademik dari tulisan ini bertujuan memperluas dan meningatkan kualitas kajian-kajian keagamaan berbasis nilaibudaya di suatu wilayah spesifik di Indonesia. Jika dilihat secara praktis, studi ini dapat bertujuan merangsang penentuan kebijakan kultural dan keagamaan yang berbasis nilai lokal, tidak perlu seragam di tiap daerah, lebih efektif, simultan dan berkelanjutan, serta merangsang keikutsertaan masyarakat lokal yang lebih aktif, sehingga dapat melanjutkan prosesnya secara sadar tanpa perlu berbasis pada program-program pemerintah.

\section{Tinjauan Pustaka}

Konsep karakter dan karakter bangsa dapat dilihat baik dari bidang ilmu humaniora maupun kependidikan. Pemerintah Republik
Indonesia melalui Kementerian Pendidikan dan Kebudayaan telah merumuskan Kebijakan Nasional Pembangunan Karakter Bangsa (2010). Dalam naskah tersebut, dirumuskan konsep karakter dan karakter bangsa sebagai berikut: Karakter adalah nilai-nilai yang khas-baik (tahu nilai kebaikan, mau berbuat baik, nyata berkehidupan baik, dan berdampak baik terhadap lingkungan) yang terpateri dalam diri dan terejawantahkan dalam perilaku. Karakter secara koheren memancar dari hasil olah pikir, olah hati, olah raga, serta olah rasa dan karsa seseorang atau sekelompok orang. Karakter merupakan ciri khas seseorang atau sekelompok orang yang mengandung nilai, kemampuan, kapasitas moral, dan ketegaran dalam menghadapi kesulitan dan tantangan (2010:10). Sementara itu, karakter bangsa adalah kualitas perilaku kolektif kebangsaan yang khas-baik yang tecermin dalam kesadaran, pemahaman, rasa, karsa, dan perilaku berbangsa dan bernegara sebagai hasil olah pikir, olah hati, olah rasa dan karsa, serta olah raga seseorang atau sekelompok orang. Karakter bangsa Indonesia akan menentukan perilaku kolektif kebangsaan Indonesia yang khasbaik yang tecermin dalam kesadaran, pemahaman, rasa, karsa, dan perilaku berbangsa dan bernegara Indonesia yang berdasarkan nilai-nilai Pancasila, norma UUD 1945, keberagaman dengan prinsip Bhinneka Tunggal Ika, dan komitmen terhadap NKRI (2010:10).

Apabila rumusan tersebut dipahami dari paradigma kebudayaan, jelas bahwa persoalan karakter baik secara individual maupun secara kelompok merupakan bagian dari kebudayaan. Hal tersebut merupakan sistem gagasan yang menjadi pedoman bagi seseorang maupun sekelompok orang dalam berperilaku atau bertindak. Hal itu diperoleh dengan belajar kebudayaan. Upaya mempelajari kebudayaan sendiri menurut antropolog dapat dipilah atas proses internalisasi, proses sosialisasi dan proses enkulturasi (Koentjaraningrat, 2009: 185 - 191).

Adapun proses internalisasi adalah proses panjang sejak individu dilahirkan sampai ia hampir meninggal. Individu belajar menanamkan dalam kepribadiannya segala perasaan, hasrat, nafsu, dan emosi yang diperlukan sepanjang hidupnya. Selanjutnya dijelaskan bahwa: Manusia mempunyai bakat yang telah terkandung dalam gennya untuk mengembangkan berbagai macam perasaan, hasrat, nafsu, dan emosi dalam kepribadian individunya, tetapi wujud dan pengaktifan dari berbagai macam 
isi kepribadiannya itu sangat dipengaruhi oleh berbagai macam stimulasi yang berada dalam sekitaran alam dan lingkungan sosial maupun budayanya. (Koentjaraningrat, 2009: 185 - 186).

Bagi antropolog, mempelajari keberadaan kebudayaan dapat dilakukan dengan mempelajari adat istiadat pengasuhan anak atau child training practices. Koentjaraningrat memberi contoh salah satu karya yang dihasilkan oleh dua antropolog yakni, Margaret Mead dan F.C. McGregor berjudul: Children and Ritual in Bali (1951). Selain itu, ada juga kajian dari Jane Belo tentang Lukisan Anakanak di Bali dan James T. Siegel berjudul: Anakanak dalam Keluarga. Kedua tulisan ini merupakan bab X dan XI dari buku editan T.O. Ihromi, berjudul: Pokok-pokok Antropologi Budaya (1980). Kajian ini memberi perhatian pada kehidupan anak-anak sebagai bagian proses internalisasi dan sosialisasi. Kajian semacam ini juga dilakukan oleh antropolog Meutia Swasono-Hatta dan koleganya dalam buku berjudul: Kehamilan, Kelahiran, Perawatan Ibu dan Bayi dalam Konteks Budaya (1998) dan Chalidjah Hasan, berjudul: Kelahiran dan Pengasuhan Anak di Pedesaan Aceh Besar (1977).

James T. Siegel dalam karyanya Anak-anak dalam Keluarga menggambarkan kehidupan anakanak dalam keluarga pada masyarakat Aceh. Ada dua hal yang menarik yaitu pertama, proses pembiasaan bagi anak laki-laki untuk benar-benar menjadi lakilaki, begitu juga sebaliknya dengan anak perempuan agar benar-benar menjadi perempuan. Kedua, ada perlakuan khusus bagi anak bungsu atau anak yang lebih muda pada saatnya jika dibandingkan dengan anak yang lebih tua. Pembiasaan ini melalui ungkapan, nasihat serta larangan mulai dari halhal sederhana. Misalnya, Siegel mencontohkan bagaimana seorang nenek memarahi anak lelaki berusia 8 tahun yang sedang memperhatikan bagaimana cara membuat kue. Ungkapan yang dikatakan adalah tempat anak laki-laki bukan di dapur. Semakin besar anak-anak laki-laki dibiasakan untuk bermain-main di luar rumah dan tidur di meunasah. Kalau ada anak laki-laki seusia 10-13 tahun masih lebih suka di rumah, ungkapan yang sering ditujukan kepada anak-anak seperti itu adalah anak yang masih menyusui. Sebaliknya, anak perempuan yang semakin menanjak dewasa, semakin dibatasi untuk keluar rumah.

Kajian Chalidjah Hasan berjudul: "Kelahiran dan Pengasuhan Anak di Pedesaan Aceh Besar" merekam perlakuan orang tua, mulai dari bayi saat lahir terlebih dahulu diperdengarkan kalimat Allah dengan membisikkan azan di telinga kanan dan ikamah di telinga kiri. Orang yang membisikkan azan adalah dalam hal ini ayah atau kalau ayah tidak ada, maka kakek atau paman atau keluarga lainnya. Begitu pula, ketika si bayi mau ditidurkan, yang dilantunkan adalah salawat. Hanya saja, penulis tersebut tidak menyertakan versi salawat yang dilafalkan. Chalidjah Hasan juga mencatat, dalam hal menyusui anak, tidak ada pengaturan atau penjadwalannya. Setiap bayi merengek langsung disusui. Hal ini dapat ditafsirkan, tidak ada proses pembiasaan pada anak-anak lewat pemberian makanan atau ASI. Hal serupa juga ditemui pada kebiasaan buang air. Chalidjah Hasan mencatat, tidak ada pembiasaan pada bayi untuk buang air kecil maupun air besar, sehingga bayi-bayi yang sudah berusia 2 hingga 3 masih buang air di celana. Proses sosialisasi bagi anak-anak di Aceh baru ditemukan ketika mereka menanjak usia pubertas. Itupun lebih diserahkan pada guru mengaji atau sekolah seperti Meunasah. Biasanya anak laki-laki belajar di Meunasah, sedangkan pendidikan anak perempuan diserahkan kepada teungku ineung. Pelajaran yang diutamakan adalah mengaji dan belajar sembahyang (1977: 131-139).

\section{METODE PENELITIAN}

Untuk mengetahui bagaimana proses internalisasi nilai dalam pola pengasuhan anak pada masyarakat Kampung Jawa di Tondano, digunakan metode penggunaan data individu (Koentjaraningrat, 1977: 197-214). Dijelaskan, data pengalaman individu dimaksud bahan keterangan mengenai apa yang dialami oleh individu-individu tertentu sebagai warga dari suatu masyarakat yang sedang menjadi obyek penelitian" (1977:197). Lebih lanjut dijelaskan bahwa kegunaan data semacam itu dalam hal melakukan penelitian terhadap masyarakat yang bersangkutan adalah bahwa si peneliti dapat memperoleh suatu pandangan dari dalam, melalui reaksi, tanggapan, interpretasi dan penglihatan para warga terhadap dan mengenai masyarakat yang bersangkutan (1977: 209). Penelitian ini menggunakan teknik pengumpulan data dengan wawancara, observasi dan FGD (Focus Group Discussion).

Sehubungan dengan rumusan masalah di atas, individu yang dipilih adalah informan yang berhubungan dengan hal pengasuhan anak dalam hal ini ibu-ibu. Dua dari informan yang dipilih merupakan representasi dari kelompok neneknenek yang sudah mempunyai cicit, tiga informan 
mewakili ibu-ibu yang juga sudah menyandang status nenek; dan seorang informan lainnya dari generasi ibu-ibu muda. Dari generasi nenek-nenek adalah Nenek Arbaya (99 tahun) dan Nenek Gaya (90 tahun). Generasi tengah, Ibu Tarwiah (74 tahun), Ibu Wati (60 tahun) dan Ibu Ria (61 tahun) dan generasi ibu muda, Mama Hanna (34 tahun).

\section{PEMBAHASAN}

\section{Latar Historis dan Sketsa Demografi Masyarakat Jaton}

Kata Jaton, baik untuk Orang Jaton maupun Kampung Jaton merupakan kata yang tidak asing bagi penduduk Sulawesi Utara. Jika orang mengucapkan kata Orang Jaton, yang dimaksud adalah warga kampung Jawa-Tondano. Selanjutnya, kalau orang menyebut kampung Jaton yang dimaksud adalah sebuah pemukiman yang secara administratif berada di wilayah Kecamatan Tondano Timur. Sebutan Jawa-Tondano merujuk pada kelompok masyarakat keturunan pengikut Kiai Modjo dan Pangeran Diponegoro, baik yang menetap di Kampung Jawa Tondano di wilayah Tondano, Kabupaten Minahasa; maupun di kampung Saronsong, Kota Tomohon, kampung Bojonegoro, Tompaso Baru, kabupaten Minahasa Selatan; Kampong Ikhwan, Doloduo, Kabupaten Bolaang-Mongondow, Propinsi Sulawesi Utara; Reksonegoro, Yosonegoro dan Kalioso di Gorontalo dan Acango dekat Jailolo, Halmahera.

Mereka adalah hasil perkawinan dan asimilasi budaya dari suku bangsa Minahasa dengan suku bangsa Jawa. Berbeda dengan kehadiran warga kelompok-kelompok etnis yang merantau; kehadiran masyarakat Jawa-Tondano berawal dari Kiai Modjo bersama 62 orang pengikutnya yang diasingkan di wilayah keresidenan Manado pada awal bulan Mei tahun 1830 (Carey, 2012: 976). Mereka adalah bagian dari 72 orang prajurit "Perang Diponegoro" yang ditangkap oleh Pemerintah Hindia Belanda kemudian diasingkan (Peter Carey, 2012, 2014; Tim Babcock, 1989). Menurut Carey, pada tahun 1831, delapan orang di antara mereka mengawini wanita Minahasa yang pada waktu itu belum memeluk agama Kristen. Setelah itu, secara berturut-turut mereka mengawini wanita setempat, ada yang sudah memeluk agama Kristen dan menjadi mualaf, ada pula yang masih memeluk agama suku atau oleh para penulis Belanda, antara lain N. Graafland menyebutnya sebagai Alfurs.

Selain pengikut Kiai Modjo atau dalam dokumen sejarah disebut Kanjeng Kiai Goeroe
Mojo; pada tahun yang sama, beberapa orang dalam rombongan Pangeran Diponegoro bergabung karena tidak diikutsertakan bersama Diponegoro sewaktu pindah ke Makassar. Pada tahun-tahun berikutnya, Kiai Hasan Maulani dari Lengkong, Cirebon; Haji Abdulkarim dan kawan-kawannya dari Banten diasingkan ke Manado dan sebagian mereka menetap di kampung Jawa.

Selain pengikut Kiai Modjo dan Pangeran Diponegoro, ada juga yang berasal dari Kalimantan dan Sumatera. Pada tahun 1880-an, Malim Muda, Haji Abdul Halim, Si Gorak Panjang dari Sumatera Barat, pengikut Perang Paderi turut bergabung di kampung Jawa Tondano dan keturunan mereka dapat ditemukan di Kampung Jawa Saronsong, Tomohon, dan pemukiman diaspora Jaton lainnya. Ada juga dari Kalimantan seperti Gusti Pangeran Perbasari; dari Aceh, Tengku Muhammad Umar; Haji Saparua dari Ambon, dan Sayid Abdullah Assegaff peranakan Arab dari Palembang.

Para pemimpin agama (Kiai Modjo) dan para pembantunya dihormati tidak hanya semasa hidup mereka, melainkan hingga pada akhir hayatnya berupa penempatan makamnya. Kumpulan makam yang terletak di atas puncak bukit sebelah utara timur laut pemukiman, menempatkan makam para pemimpinnya pada puncaknya sedangkan para pengikutnya berada di bagian lereng bukit. Penghormatan tersebut menurun kepada anak cucunya, apalagi kepada beberapa tokoh yang mengawini putri para kepala walak di Minahasa, seperti halnya Tumenggung Pajang yang mengawini Wurenga Rumbayan, putri kepala walak Tonsea Lama; Hasan Muhammad Reksonegoro Pulukadang mengawini Samola Tumbelaka; Kiai Ngiso Pulukadang mengawini Linow Lengkong Pakasi, Gozali Modjo mengawini Ingkang Tombokan; Kiai Dadapan mengawini Rachel Tombokan, dan sebagainya (Sandiah, 2002: 28). Para keturunannya mendapat perlakuan khusus tidak hanya dari pihak warga Jaton, melainkan juga dari warga Minahasa keluarga dari para gadis yang menjadi isteri para tokoh dan anak keturunan mereka. Relasi-relasi ini pulalah yang menjadi perekat antara dua kelompok yang berbeda agama disatukan oleh hubungan kekerabatan.

Karena latar belakang tersebut penduduk Jaton merupakan permeluk Islam yang taat dalam menjalankan syariat agama. Berbagai upacara baik yang berhubungan dengan kalender agama maupun daur hidup individu tidak lepas dari peradaban Islam, seperti Selamatan Asura, Rebo 
Kasan, Meludan, Mi'raj, Aderan, Punggoan, Selametan, Maleman, Takbiran, Bakdo Ketupat dan sebagainya. Ritual yang berhubungan dengan daur hidup individu misalnya, mulai dari tingkepan, jagongan, palelean, amongamong, puputan, akeka, taropan, malam bidodareni, temonan, sumsoman, dan beberapa ritual yang berhubungan dengan kematian. Pada setiap ritual tersebut di atas, alunan Salawat, baik itu Salawat Jowo maupun Salawat Melayu (hadra, rodatan) dilantunkan seperti pada upacara Slametan yang dilakukan sesuai tahapan serta tujuannya (Babcock, 1989: 55-122).

Pemukiman awal dari para pengikut Kiai Modjo dan Pangeran Diponegoro ini berada di wilayah distrik Tonsea Lama, atau bagian utara Kampung Jawa Tondano sekarang dan dikenal dengan nama Tegalrejo. Seiring dengan bertambahnya jumlah penduduk, warga mendirikan rumah di bagian selatan Tegalrejo dan sekarang dikenal sebagai Kampung Jawa. Sebagian lainnya memilih untuk pindah ke tempat yang baru dan membuka pemukiman baru yang sekarang dikenal dengan nama Kampung Jawa Saronsong, Tomohon; Bojonegoro, Tompaso Baru, Minahasa Selatan; Reksonegoro, Yosonegoro dan Kalioso, di Gorontalo.

\section{Upacara Daur Hidup Orang Jaton dan Nilai Islami di Dalamnya}

Penjelasan ini terutama mengacu pada upacara sepanjang daur hidup individu, dengan mengutamakan paparan tentang perkawinan, kehamilan, dan kelahiran. Hal ini dilakukan karena upacara-upacara sepanjang daur hidup tersebut memiliki arti khusus bagi kehidupan orang Jaton dan benar-benar disiapkan, karena tidak hanya memiliki arti yang penting dalam arti kepercayaan agama, namun juga memiliki arti penting secara sosial.

Pada sekitar upacara pernikahan yang memiliki arti khusus dalam kehidupan berkeluarga. Orang Jawa Tondano sama halnya dengan orang Tondano dan Minahasa pada umumnya menempatkan upacara pernikahan sebagai peristiwa yang melibatkan keluarga kedua belah pihak. Tidaklah mengherankan jika upacara pernikahan di kampung Jawa Tondano dirayakan secara meriah dan pasti membutuhkan pembelanjaan yang besar. Babcock (1989: 78) mencatatnya dalam sebuah ungkapan yang sangat ekspresif, sebagai berikut:

"...Weddings are the most festive, most expensive and most elaborate of Kampung
Jawa's rites of passage. Wedding usually involve greater numbers and greater diversity of people (two extended sets of kin, neighbors, friends, the youth, the 'modern' sector of the village) than any other ritual in this category..."

(“... Pernikahan adalah hal yang paling mewah, paling mahal serta paling rumit dalam rangkaian upacara sepanjang daur hidup manusia (rites de passage) di Kampung Jawa Tondano. Pernikahan senantiasa melibatkan banyak orang, mulai dari keluarga kedua belah pihak, tetangga, sahabat, anak muda, dan sector modern di kampung, dibandingkan dengan upacara ritual lainnya sepanjang daur hidup individu.")

Selama satu tahun setengah yaitu dari bulan Januari 1974 hingga bulan Juni 1975, Babcock menetap di kampung Jawa Tondano melakukan penelitian untuk disertasinya, ia mencatat bahwa upacara pernikahan yang begitu ramai baik menjelang dilakukannya akad nikah yang selalu dilaksanakan di masjid yang ada maupun pesta pora setelah akad nikah di rumah pengantin, menuntut banyak persiapan dan pengeluaran.

Sama halnya dengan sejumlah masyarakat etnis di Nusantara, pernikahan di kampung Jawa Tondano diawali dengan upacara melamar. Pada saat itu pula apabila lamaran diterima, ditentukan segala macam tata cara penyelenggaraan upacara pernikahan termasuk di dalamnya besaran biaya serta jenis-jenis materi yang akan diserahkan oleh pihak keluarga pengantin pria kepada pihak keluarga pengantin wanita. Hal terakhir ini dikenal dengan tradisi antar harta. Selain antar harta, dikenal pula adanya seserahan atau juga antaran yang jumlah dan jenisnya beragam tergantung pada keadaan ekonomi dari keluarga yang menikahkan anaknya. Paling umum adalah sejumlah uang yang disebut teteles pupur bagi pengantin wanita. Ada pula yang menyerahkan sprei, bantal guling, kelambu, lemari pakaian, stelan baju untuk pengantin wanita termasuk sepatu dan perhiasan. Keluarga pihak pengantin pria pada saat yang sama juga menyerahkan belanja dan material kebutuhan pesta seperti sapi, kambing, ayam, dan beras.

Pelaksanaan perkawinan menurut adat dilakukan selama dua hari tiga malam. Hari pertama disebut taropan, orang tua dan keluarga diundang untuk persiapan acara puncak. Malam harinya disebut bidodareni, pengantin wanita didandani 
dan duduk sendiri di pelaminan (kobongan) dimeriahkan dengan nyanyian-nyanyian perpisahan oleh teman-teman wanitanya. Acara ini disebut acara dames. Pada keesokan harinya, pukul enam pagi diantarkan hantaran berupa bahanbahan yang akan dimasak untuk pesta perkawinan.

Selama perjalanan dari rumah pengantin lakilaki ke rumah pengantin perempuan dilantunkan Slawatan Jowo. Pukul sebelas siang diadakan Akad nikah yang dilangsungkan di masjid atau juga di rumah pengantin wanita; apabila akad nikah dilangsungkan di masjid, usai akad nikah pengantin laki-laki berganti pakaian lalu diiring ke rumah pengantin wanita. Pengantin laki-laki berjalan di tengah, di depannya adalah rombongan Slawatan Melayu dan di belakang adalah rombongan Slawatan Jowo. Setibanya di rumah pengantin wanita diadakan ritual gepokan, yaitu pengantin laki-laki menyentuh dahi pengantin wanita dengan membaca Bismillah. Upacara puncak pada siang harinya disebut tomonan.

Dalam acara ini disajikan ambeng. Malam kedua, kedua pengantin duduk di pelaminan dihibur dengan musik, nyanyian-nyanyian, pidatopidato dan nasihat perkawinan. Pada malam ketiga, diadakan Sumsoman, acara ucapan terima kasih dari keluarga pengantin kepada sanak saudara, handai taulan yang sudah bekerja menyukseskan acara pesta perkawinan. Sajian khas ialah janganan, sunsom sambal goreng kepala sapi.

Upacara-upacara ritual bagi seorang ibu diawali pada masa kehamilan. Seorang ibu yang hamil pertama pada waktu kandungan berusia tujuh bulan diadakan upacara ritual yang disebut tingkepan. Tingkepan dilakukan pada pagi hari, dipimpin oleh Imam atau pemuka agama diisi dengan membaca doa selamatan. Setelah pembacaan doa selamatan, para tamu diberi suguhan berupa janganan atau beragam-macam masakan sayur mayor, gudek, sambal goreng, lauk ayam engkong atau ayam yang dimasak utuh, pisang rebus, kacang tanah rebus, ketupat, bubur merah putih, serundeng, dan kue apam. Sajian makanan ini ditempatkan di satu wadah yang disebut ambeng, dan biasanya satu ambeng disajikan untuk lima orang. Kalau tidak habis dimakan, sisanya dibungkus oleh tamu untuk dibawa pulang. Bungkusan makanan ini disebut berkat.

Penyelenggaraan Selamatan pada upacara tingkepan sangat diperhatikan karena menurut warga akan mempengaruhi karakter dan perilaku si jabang bayi ketika dia sudah lahir. Seorang anak berkarakter kurang baik atau dalam istilah setempat kurang ajar sering disebut kurang janganan. Ini sering diasosiasikan karena pada waktu selamatan, jenis sayuran dan kue serta makanan yang disajikan kurang lengkap dari yang diharuskan dalam tradisi. Tiap memulai suatu pekerjaan termasuk mengolah masakan, selalu diawali dengan mengucapkan Bismillah.

Ketika si bayi lahir, proses internalisasi awal adalah sang ayah atau kakek atau paman apabila si ayah tidak berada di tempat, membisikkan kalimat Allah, yaitu pada telinga kanan dilafalkan azan, dan pada telinga kiri dilafalkan ikamah. Adapun lafal Azan yang dibisikkan ke telinga kanan bayi adalah sebagai berikut:

\begin{tabular}{ll}
\hline Lafal & Terjemahan \\
\hline Allahu Akbar, Allahu Akbar, Allahu Akbar; & Allah Maha Besar, Allah Maha Besar, Allah Maha Besar; \\
Asyhadu an laa Ilaahailallah, Asyhadu an laa & Aku bersaksi bahwa tidak ada Tuhan selain Allah, \\
Ilaahailallah; & Aku bersaksi bahwa Muhammad itu Utusan Allah, \\
Asyhadu anna Muhammadan Rasulullah, & Aku bersaksi bahwa Muhammad itu Utusan Allah; \\
Asyhadu anna Muhammadan Rasulullah; & Marilah Salat/Sembahyang, Marilah Salat/Sembahyang; \\
Hayya 'Alas-shalaah, Hayya Alas-shalaah; & Marilah Menuju Kemenangan, Marilah Menuju Keme- \\
Hayya 'Alal-falaah, Hayya 'Alal-falaah; & nangan; \\
Allahu Akbar, Allahu Akbar; & Allah Maha Besar, Allah Maha Besar; \\
Laa Ilaaha Ilallaah. & Tidak ada Tuhan selain Allah \\
\hline
\end{tabular}


Sedangkan lafal Ikamah yang dibisikkan pada telinga kiri si bayi adalah sebagai berikut:

\begin{tabular}{ll}
\hline Lafal & Terjemahan \\
\hline Allahu Akbar, Allahu Akbar & (Allah Maha Besar, Allah Maha Besar, \\
Asyhadu an laa Ilaahailallah, & Aku bersaksi bahwa tidak ada Tuhan Selain Allah, \\
Asyhadu anna Muhammadan Rasulullah, & Aku bersaksi bahwa Muhammad itu utusan Allah, \\
Hayya 'Alas-shalaah, & Marilah Salat/Sembahyang, \\
Hayya 'Alal-falaah, & Marilah menuju kemenangan, \\
Qad Qaamatish-shalaah, Qad Qaamatish-shalaa, & Dirikanlah Salat, Dirikanlah Salat, \\
Allahu Akbar, Allahu Akbar, & Allah Maha Besar, \\
La Ilaaha Ilalaah & Tidak ada Tuhan selain Allah) \\
\hline
\end{tabular}

Ketika si bayi sudah berusia tujuh hari, diadakan kunjungan oleh sanak saudara dan kenalan serta tetangga. Kunjungan ini disebut jagongan. Pada hari ketujuh sesudah melahirkan, ibu dimandikan dengan uap air yang sudah diberi ramuan berupa beragam dedaunan yang menimbulkan efek aroma wewangian. Untuk si bayi diadakan acara among-among, yaitu dengan mengundang beberapa anak diberi makan ambeng dan selesai makan masing-masing anak diberi uang.

Ketika anak-anak balita sudah mulai belajar bicara, baik ayah dan ibunya maupun kakek dan neneknya mulai memperkenalkan ungkapan-ungkapan yang ada dalam peradaban Islam, misalnya setiap masuk dan keluar rumah mengucapkan Assalamu Alaikum dan atau membalas salam dengan Wa'alaikum Salam. Anakanak diajari bahwa setiap mengawali sesuatu harus mengucapkan kata Bismillah, setiap memperoleh nikmat mengucapkan Alhamdulilah, Insya Allah dan sebagainya. Cara menjabat tangan dan mencium tangan dari orang tua sudah mulai ditanamkan semenjak kecil. Ketika anak-anak sudah mulai fasih bercakap-cakap, mereka diperkenalkan pada ayatayat pendek Al-Quran, sebelum mereka diserahkan kepada guru mengaji untuk belajar mengaji. Diikutsertakan ketika mau sembahyang, juga sudah dipraktikkan semenjak anak-anak masih berusia tiga hingga lima tahun. Ada pula yang pada usia mudanya sudah ikut puasa pada bulan Ramadan.

Sunatan atau khitanan merupakan upacara ritual keagamaan yang dilakukan kepada anakanak yang sudah cukup umur. Acara sunatan atau khitanan diselenggarakan pada pagi hari. Pada malam hari sebelum acara sunatan, diadakan Khatam Qur'an dengan maksud agar anak tersebut sesudah dikhitan sempurnalah keislamannya dan baginya diwajibkan melaksanakan semua perintah yang dianjurkan oleh agama. Selesai acara khitan, disajikan ambeng.
Khatam Alquran merupakan kebanggaan baik bagi anak-anak dan terutama pula bagi orang tua. Pada saat seperti itu diselenggarakan selamatan, mulai dari sederhana sekedar makan kue dan minum teh, hingga pesta makan-minum. Kesemuanya tergantung pada keadaan ekonomi orang tua mereka.

Ketika anak-anak baik lelaki maupun perempuan dipandang sudah paham membaca, mereka diserahkan kepada guru mengaji untuk belajar isi Alquran serta tatacara sembahyang. Ada pula orang tua yang membimbing anak-anaknya menghafal ayat-ayat Alquran, seperti halnya peneliti temukan pada kasus Hanna seorang Balita di Jaton yang diajari oleh ibundanya sebagai persiapan sebelum ia diserahkan kepada guru mengaji.

Pergaulan antara anak-anak laki-laki dan anak-anak perempuan mulai dibatasi ketika mereka menanjak pada periode pubertas. Pendidikan atau tepatnya pemberian informasi tentang seksual masih sangat dibatasi dan bahkan dianggap tabu. Pengetahuan tentang hal-hal seksual akan mereka peroleh sejalan dengan pertambahan usianya dan tidak mereka peroleh secara formal dan langsung dari orang tua. Ketika mendekati usia akil-baliq yang dilakukan oleh orang tua adalah mulai membatasi pergaulan anak-anak dengan larangan dan nasihat.

\section{Proses Internalisasi Nilai Bagi Kalangan Warga Jaton}

Sejumlah buku teks etnografi merekam bahwa pada hampir di semua kelompok masyarakat tradisional, persoalan internalisasi nilai tidak dipelajari lewat pranata-pranata yang ada selain melalui pengalaman orang tua dan pengalaman ini kemudian dilakoni serta diwariskan secara turuntemurun. Untuk itulah maka pemaparan tentang proses internalisasi nilai dalam tulisan ini tidak disajikan secara umum sebagai temuan penelitian, melainkan lewat pengalaman-pengalaman individu 
sebagaimana dijelaskan dalam bagian Metode. Penyajiannya dilakukan secara berjenjang dan melalui pengalaman tiga generasi yang masih ada di kampung Jawa Tondano. Secara umum, hampir tidak ada pergeseran cara dalam proses internalisasi. Generasi yang lebih muda meneruskan praktik internalisasi seperti yang mereka peroleh dan alami dari orang tua mereka.

Praktik internalisasi ini, misalnya terlihat dari tuturan yang dilantunkan dari generasi yang tua kepada yang lebih muda. Salah satu informan, yaitu nenek Arbaya yang berusia 99 tahun mengatakan bahwa dia sering diminta memberi nasihat dengan cara melantunkan Salawat, berpantun dan lewat ungkapan-ungkapan. Pada hari tuanya, dia dijaga oleh anak-anaknya, dan putra bungsu beserta istrinya yang tinggal bersama di rumah peninggalan orang tua mereka. Salawat dan Pantun yang dilantunkan ini berisi ajaran-ajaran utama dalam Islam sekaligus pedoman berperilaku. Misalnya yang terekam dalam beberapa penggalan Salawat, Pantun dan ungkapan-ungkapan yang dia tuturkan dan masih digunakan menjadi media internalisasi nilai bagi orang Jaton seperti terlihat pada tabel di bawah ini:

Tabel 1. Beberapa Contoh Media Internalisasi Nilai Budaya Serta Isinya Pada Warga Jaton

\begin{tabular}{ll}
\hline LANTUNAN SALAWAT & PANTUN \\
\hline Laailahailallah & Selain guru lain ajaran \\
Hulaailahailallah & Lainnya dulu lain sekarang \\
Laailahailallah & Minyak tanah si minyak baru \\
Muhammadarrasulullah & Tahun lama si gaji baru \\
Siapa suka dapat selamat & Pisang emas bawa balayar \\
Belajar ilmu sehingga tamat & Ambilnya satu simpan di laci \\
Kepada Allah wajib ibadah & Hutang emas boleh kubayar \\
Pakai atoran baca sahadat & Hutanglah budi membawa mati \\
Jangan bermain jangan bersedu & Ada ubi ada talas \\
Jangan pamalas jangan pentidur & Ada budi harus dibalas \\
Akhirnya kita menjadi tanah & Segala amal nyata terbayang \\
Mendapat siksa berbagai warna & Punya semuanya yang kasih sayang \\
\hline & \\
\hline UNGKAPAN-UNGKAPAN & KATA-KATA NASIHAT \\
\hline Hukum Adat: 5 perkara & Kejarlah duniamu, seakan-akan kau tidak mati \\
Kalau ada, bakase (Kalau ada kelebihan, berilah & Kejarlah akhiratmu, seakan-akan kau mati sebentar/ \\
kepada yang membutuhkan) & besok. \\
Kalau nyanda ada, baminta (Kalau tidak memi- & \\
liki, mintalah) & Amalan dalam beribadah (hidup): \\
Kalau bapinjam, kase pulang (kalau meminjam, & Kejujuran \\
jangan lupa mengembalikannya) & Kebaikan \\
Kalau bautang, bayar (Kalau berhutang, bayarlah) & Ketakutan \\
Kalau ada amanat, sampaikan (Kalau diberi am- & Keberanian \\
anat, sampaikan) & Ke"malu”an \\
$\begin{array}{l}\text { Rukun Syahadat: } 4 \text { perkara } \\
\text { Ditasbihkan dalam hati }\end{array}$ & \\
Diikrarkan dengan lidah & \\
Diamalkan & \\
Diyakini & \\
\hline & \\
\hline
\end{tabular}


Penekanan terhadap norma-norma agama Islam sebagai dasar mendidik putra-putri jelas terlihat dalam lantunan-lantunan dalam tabel tersebut di atas. Dimana, selain lewat kegiatankegiatan resmi dan seremoni ataupun kegiatan yang menuntut situasi sosial, namun proses internalisasi ini justru lebih sering dilakukan lebih personal, misalnya ketika anak-anak masih bayi, mereka dinina-bobokan atau istilah setempat disebut balelo/ baondo, dengan mendendangan Salawat Nabi. Ini merupakan kebiasaan atau tradisi para ibu di Jaton yang diwarisi serta dilakoni turun-temurun.

Dari sudut pandang yang mendengarkan, terutama anak-cucu dalam usia Balita hingga SD, kebiasaan mendidik seperti ini seringkali menjadi daya tarik tersendiri terutama dalam soal berpantun. Bagi para penutur, yaitu para orang tua, ada kesadaran kolektif bahwa: meskipun anak-anak belum paham makna serta pesan yang terkandung dalam pantun nasihat yang nenek tuturkan, namun, lambat laun dan secara tidak disadari isi pantun itu mereka hafal dan pada saat mulai akil baliq, mereka mulai memahaminya.

\section{Makna Nilai Islami dalam Bait-Bait Salawat dan Syair Nasihat di Jaton}

Kesan sepintas ketika membaca dan mendengar tuturan Salawat yang dituturkan oleh informan utama Nenek Arbaya (99 tahun) dan dikutip pada bagian sebelumnya, tampak bahwa nilai ketakwaan merupakan hal yang menonjol baik dalam setiap bait Salawat maupun dalam bait-bait pantun dan nasihat yang ada. Ketakwaan menjadi inti atau dalam istilah logika kebahasaan sebagai premis major di mana premis-premis minor diturunkan berikut ini:

Siapa suka dapat selamat

Belajar ilmu sehingga tamat

Kepada Allah wajib ibadah

Pakai atoran baca sahadat

Jangan bermain jangan bersedu

Jangan pemalas jangan pentidur

Akhirnya kita menjadi tanah

Mendapat siksa berbagai warna

Nilai yang dapat ditangkap dari tuturan ini adalah bahwa tujuan belajar ilmu sehingga tamat sebagaimana ada pada bait kedua terbaca pada bait ketiga dan keempat yaitu 'kepada Allah wajib ibadah' dan 'pakai atoran baca sahadat'. Pada aras pertama atau pada permukaannya, anjuran dalam bait kedua 'belajar ilmu hingga tamat' adalah belajar ilmu agama. Seorang muslim pada dasarnya harus paham ilmu agama, minimal belajar mengaji/ membaca Alquran sampai selesai (khatam). Selain itu, menjalankan Rukun Islam yang terdiri atas lima perkara yaitu: 1) mengucap dua kalimat syahadat;2) sembahyang lima waktu;3) puasa di bulan Ramadan; 4) membayar zakat, dan 5) naik haji apabila mampu. Agar dapat belajar hingga tamat, maka si "aku lirik" pada kumpulan bait selanjutnya menganjurkan 'jangan bermain jangan bersedu, jangan pamalas jangan pentidur'. Kalau si pembelajar hanya bermain-main, pemalas, dan penidur, atau tidak serius, maka pada bait selanjutnya ditegaskan bahwa 'akhirnya kita menjadi tanah, mendapat siksa berbagai warna. Pada bait-bait selanjutnya masih juga diingatkan 'jangan lupa pesanan guru, masuk lubang seorang diri'. Pada saat sendiri seseorang disoal 'siapa Tuhanmu'; dan pada bait selanjutnya dipesankan, 'jikalau ada jawabmu salah, kepala dipalu badan dihela'.

Ada juga bagian II Salawat yang sebagai penegasan dari hal ketakwaan bahwa "kamilah ini semua hamba Allah, hanyalah Allah kami bergantung, hanyalah Allah yang boleh menulung; boleh menulung hapuskan dosa, jauhkan kami dari segala siksa". Formulasi keyakinan yang mendasari ketakwaan didasarkan pada kesadaran bahwa si "aku lirik" atau si penutur Salawat ini adalah hamba Allah. Pemahaman terhadap frasa 'hamba' menunjukkan sikap rendah hati serta berbagai karakter lainnya sebagaimana yang dicontohkan oleh Nabi Muhammad Saw dan para sahabatnya yang sering dikisahkan oleh guru mengaji.

Bagian akhir dari Salawat bagian II menegaskan bahwa ketakwaan mendasari karakter dan perilaku hidup memiliki tujuan yaitu 'negeri akhirat sobat malaikat'. Untuk itu, agar menjadi 'sobat malaikat, 'buat ibadah sehari-hari'. Kalimat ini mengandung perintah agar menjalankan ibadah setiap hari.

Selain itu, ada juga bagian nasihat yang memiliki tujuan menanamkan nilai-nilai penghormatan kepada orang tua, bakti kepada orang tua merupakan salah satu nasihat dan perintah yang terkandung dalam tuturan nasihat. Mengapa harus berbakti kepada orang tua? Secara panjang lebar si mengungkapnya dalam bait-bait syair nasihat seperti di bawah ini.

1Isi baris-baris salawat ini ditulis sebagaimana dituturkan, tidak dilakukan editing bahasa. 
Syair nasihat bagi ikhwani

Itu kenyataan wilur wal idaini

Dengarkan kiranya perkataan ini

Supaya sentosa hidup dan mati.

Difardukan oleh Allah Izati

Kepada ibu bapak kita berbakti

Dari hidupnya sampai mati

Tulus dan ikhlas di dalam hati

Bakti kepada orang tua adalah kewajiban yang diperintahkan oleh Allah. dan perilaku bakti harus secara tulus dan ikhlas. Hal-hal di atas menunjukkan, bahwa dalam hal content, ketakwaan atau hubungan vertikal terhadap Allah SWT ditekankan secara utama dalam praktik-praktik internalisasi nilai budaya. Kemudian, diikuti dengan hubungan horizontal ke sesama manusia, terutama kepada orang tua, baik dalam hal memberi penghormatan dan kasih sayang serta bagaimana sepantasnya berlaku.

\section{Salawat Sebagai Media Internalisasi Nilai Budaya dan Implikasi Praktiknya}

Telah disinggung pada awal tulisan ini bahwa Salawat merupakan salah satu media internalisasi nilai budaya, terutama nilai-nilai yang didasarkan pada ajaran agama dan peradaban Islam. Ajaran agama menjadi semacam "cantolan", seperti yang dicontohkan, yaitu nilai ketakwaan. Dari nilai ketakwaan ini kemudian dirinci ke berbagai perilaku yang harus dijalani oleh warga pendukung kebudayaan dalam hal ini warga masyarakat Jawa Tondano.

Salawat dalam kehidupan sehari-hari didendangkan tidak hanya pada acara-acara pesta melainkan juga ketika si ibu mau menidurkan anaknya. Para ibu yang menjadi mediator paling utama dalam menggunakan Salawat sebagai media internalisasi nilai-budaya. Dari penuturan informan, mereka mendendangkan Salawat saat menggendong anaknya maupun ketika menidurkan anak-anak atau membujuk mereka agar berhenti menangis, sebagai satu kebiasaan atau tradisi yang juga mereka pernah alami. Di sini telah terjadi proses pembiasaan. Mulai dari mendengar kata-katanya. Lama-kelamaan, ketika beranjak dewasa, mereka menjalankannya karena tradisi dan kebiasaan.

Versi salawat bisa berbeda-beda dan tergantung pada situasi seperti apa Salawat dilantunkan. Suasana di seputar acara perkawinan dan acara atau upacara sepanjang daur hidup lainnya seperti kelahiran dan kematian, seringkali mengilhami warga berSalawat. Pada acara kematian misalnya, inti Salawat yang dilantunkan sering mengenai kehidupan menjelang kematian dan setelah mati. Di situ terselip anjuran untuk menjalankan perintah agama dan meninggalkan hal-hal yang dilarang karena kesemuanya akan melapangkan jalan ke akhirat. Pada acara dan upacara yang berhubungan dengan masa kelahiran dan perkawinan, syair-syair Salawat lebih banyak bertutur tentang bagaimana mendidik anak, membesarkan anak, menjaga keutuhan rumah tangga, saling menyayangi antara suami dan istri, bagaimana menjadi suami yang saleh dan istri yang saleha, dan sebagainya.

Tuturan pengalaman para peserta FGD dalam penelitian ini memperkuat anggapan bahwa Salawat tidak hanya berfungsi sebagai sebuah syair yang dilagukan untuk menghibur anak-anak atau warga dalam sebuah acara pertemuan. Ketika para peserta FGD mengingat kembali masa muda mereka, mereka fasih mendendangkan Salawat walaupun waktu itu belum paham arti dan maknanya. Salawat menurut pengalaman peserta FGD, memiliki perbedaan mendalam dibanding menyanyi lagu populer hingga dangdut bernafaskan ajaran agama.

Kelebihan ini menurut para informan adalah formula-formula yang berintikan ajaran agama, seperti:

\section{Laailahailallah \\ Hulaailahailallah \\ Laailahailalla \\ Muhammadarrasulullah}

Atau juga pada bagian awal versi lain dari Salawat, seperti:

\section{Laailahailallah \\ Muhammadarasulullah \\ Menjadi sifat Allah \\ Sifat menjadi kalamullah}

Bagi orang Jaton, formula kalimat inilah yang menjadi kekuatan yang membedakan Salawat dengan lagu-lagu lainnya yang dikenal ketika masih anak-anak. Ada keyakinan kuat dalam alam pikiran dan perasaan pelantun ataupun pendengarnya, sebagaimana pengakuan Eko salah seorang peserta FGD, bahwa ketika dia menumpang kendaraan sendirian dari rumah orang tuanya di Manado ke rumah kakek-neneknya di kampung Jawa Tondano, di tengah-tengah orang yang tidak dikenalnya di kendaraan umum, ia mengingat syair Salawat dalam hati dan saat itu pula dia merasa tenang 
dan akhirnya tiba di rumah kakek-neneknya tanpa halangan. Ketika dia beranjak dewasa, dia mulai paham makna dari setiap kata dalam syair Salawat dan sejak itu pula dia mulai mempraktikkannya dalam kehidupan sehari-hari. Bagaimana dia mulai belajar, dan konsep belajar di sini baginya tidak sebatas belajar ajaran agama, melainkan belajar ilmu lainnya, dan terbukti dia menyelesaikan pendidikan S-1. Atas dasar keyakinan itu pula dia tidak mengikuti jejak ayahnya menjadi tentara TNI-; juga tidak ikut jejak ibunya menjadi PNS melainkan merintis karirnya sebagai seorang wiraswasta yang terbilang sukses di usianya. Dalam hal berbakti kepada orang tua, yang bersangkutan jalani dengan mendirikan rumah tinggal yang satu halaman dengan rumah ibunya yang kini sudah menjanda. Di tengah-tengah kesibukannya sebagai seorang pebisnis, pada waktu-waktu senggang, ia memilih duduk di rumah dan bercakap-cakap dengan ibunya. Kecintaan seperti itu ia tanamkan pula kepada putrinya yang sudah mulai remaja dan selalu dekat dengan neneknya.

Bagi para informan, ada perbedaan antara syair lagu-lagu populer dengan syair-syair Salawat. Lagu-lagu populer hanya bertahan sejenak dalam ingatan. Begitu lagunya sudah tidak populer lagi, saat itu pula lagu tersebut terlupakan. Sementara syairsyair Salawat yang pernah mereka dengar terutama dari ibunya, tetap bertahan dalam ingatan dan bahkan hadir sebagai sebuah keutuhan. Maksudnya, ketika ia mendengar orang lain melantunkan syair Salawat yang sama, ia teringat pada usia berapa, dalam situasi seperti apa, ia mendengar sang ibu melantunkan Salawat tersebut. Bahkan ia juga mengingat bagaimana Nenek Arbaya melantunkan Salawat-Salawat yang ada.

\section{Seni Tutur sebagai Pembentuk Karakter Orang Jaton}

Meskipun tidak bersifat membandingkan dengan tanah leluhur mereka, kajian yang dilakukan Tim Babcock (1989: 2) menilai masyarakat Jawa Tondano "sangat khusus dan unik". Keunikannya terletak pada agama dan identitas kulturalnya. Sebagai keturunan para pemuka dan tokoh agama Islam yang melawan penjajahan Belanda dan kemudian diasingkan di tengah-tengah masyarakat yang bertransisi dari pemeluk agama suku ke masyarakat Kristiani, mereka mengembangkan sikap toleran terhadap warga di sekitarnya. Meskipun menyandang nama masyarakat JawaTondano, warganya tidak sepenuhnya berasal dari Jawa Tengah, dalam hal ini pengikut Kiai Modjo dan Perang Diponegoro, melainkan juga ada beberapa tokoh agama baik dari Jawa Barat, Sumatera, Kalimantan dan Saparua di Maluku yang diasingkan di kampung Jawa Tondano. Alasan lain bahwa setelah seabad lebih dan para keturunannya hidup berdampingan dengan warga masyarakat Minahasa, tidak dapat dipungkiri bahwa sudah terjadi akulturasi budaya. Salah satu contoh konkrit adalah bahasa yang mereka tuturkan merupakan campuran dari kata-kata dalam bahasa Jawa dan bahasa Tondano.

Sebagai keturunan dari keluarga tokoh agama Islam, tidak dapat dipungkiri bahwa mereka adalah muslim dan muslimah yang taat pada ajaran agama serta peradaban Islam. Di sisi lain, ketaatan terhadap agama dan budaya Islam tidak menjadi penghambat dalam hal bertoleransi dengan warga masyarakat yang berbeda adat dan agama di sekitarnya. Pada dasarnya, mereka tumbuh dan berkembang sebagai satu entitas yang memiliki identitas bukan Jawa dan bukan Tondano, melainkan perpaduan yang harmonis dari keduanya.

Mengacu kepada hasil penelitan Babcock di atas yang mana unsur agama Islam yang menjadi penanda khas masyarakat Jawa Tondano, maka salah satu karakter yang paling menonjol adalah ketakwaan warga masyarakat Jawa Tondano sebagai penganut ajaran Islam yang tidak menutup diri melainkan toleran terhadap tetangganya. Apakah sikap toleransi ini dilatari dengan perkawinan antara para pria Jawa dan wanita Minahasa merupakan topik menarik untuk penelitian selanjutnya. Karakter sebagai manusia-manusia yang takwa, di mana sikap ketakwaan telah mendasari perilaku rajin bekerja, rajin belajar, berbakti kepada orang tua, kesemuanya dapat ditelusuri dan berkaitan erat dengan isi syair-syair Salawat.

Karakter lain adalah berani mengambil risiko dan mudah menyesuaikan diri dengan warga di sekitarnya. Hal ini dapat ditelusuri pada kasus bagaimana warga masyarakat Jawa Tondano, mengembangkan strategi hidup berdiaspora ke Maluku Utara, Gorontalo, Bolaang-Mongondow, dan tempat lainnya di Minahasa. Berbeda dengan kehadiran warga masyarakat Jawa di beberapa lokasi transmigrasi yang ada di wilayah Propinsi Sulawesi Utara dan Propinsi Gorontalo, yang kesemuanya difasilitasi oleh pemerintah; kehadiran pemukiman warga masyarakat Jawa Tondano di wilayah kedua propinsi ini terjadi karena migrasi spontan. Mulamula satu dua keluarga yang berusaha di tempat 
yang baru. Setelah mereka melihat peluang untuk menetap di tempat yang baru, keluarganya yang masih tinggal di kampung Jawa Tondano menyusul ke tempat yang baru. Namun, mereka tetap menjaga hubungan silaturahim dengan kampung asalnya.

Karakter takwa atau ketakwaan kepada ajaran dan tuntunan agama yang menjadi dasar bagi munculnya karakter lain seperti giat belajar, giat bekerja, toleran, berbakti kepada orang tua, merupakan hasil dari pembiasaan-pembiasaan perilaku sejak masa bayi dan anak-anak yang tidak hanya dinina-bobokan oleh para ibu dengan lantunan dendang Salawat, melainkan bagaimana untaian kata dan kalimat dalam syair-syair Salawat tadi terinternalisasi seiring dengan pertumbuhan fisik dan psikis dari anak-anak menjadi remaja hingga akil balig. Ada korelasi yang kuat antara isi Salawat dan ajaran-ajaran agama dan perilaku orang dewasa yang menjadi contoh serta tokoh panutan dalam masyarakat. Ketika penelitian, para peserta FGD sependapat dengan ini, karena mereka mendapati bahwa nilai dan makna Salawat menjadi memory collective yang seringkali menjadi penyemangat hidup.

\section{PENUTUP}

Dapat disampaikan di sini, bahwa dalam hal proses internaslisasi nilai budaya berbasis nilai Islam, Para orang tua di kampung Jawa Tondano dalam hal mengasuh anak terutama anak yang masih balita, pada umumnya menggunakan seni tutur. Salah satu tradisi khususnya seni tutur yang hingga kini masih mereka pelihara adalah pantun, nasihat, syair dan utama Salawat. Salawat dilantunkan tidak hanya dalam arti doa, permohonan kepada Allah SWT, melainkan juga menjadi media internalisasi nilai budaya yang kuat dalam peradaban Islam di kampung Jawa Tondano. Salawat tidak hanya dilantunkan pada suasana upacara ritual yang berhubungan dengan daur hidup individu atau life cycles, melainkan juga menjadi doa yang didendangkan/dilantunkan pada saat meninabobokan bayi.

Penelitian ini menemukan, hampir semua ibu-ibu memiliki pengetahuan dan mampu melantunkan Salawat. Pengetahuan mereka bervariasi mulai sekadar mengetahui Salawat yang pendek hingga mereka yang mengetahui dan mampu melantunkan Salawat yang panjang dan dalam beberapa versi.

Syair-syair yang dilantunkan sewaktu menggendong dan menina-bobokan anak balita, pada umumnya kata-katanya mengandung pujian kepada Allah dan Nabi Muhammad Saw serta berupa pantun yang mengandung nasihat. Informan dari tiga generasi yang berbeda menunjukkan bahwa generasi yang lebih tua memiliki pengetahuan yang kaya tentang Salawat dibandingkan dengan generasi yang lebih muda. Hasil amatan pada generasi muda baik yang sudah menjadi ibu maupun masih anak balita seperti yang sudah dipaparkan dalam tulisan ini menunjukkan bahwa mereka masih memiliki pengetahuan yang memadai tentang syair-syair Salawat.

\section{UCAPAN TERIMA KASIH}

Dalam proses penelitian dan penerbitan artikel ini. Penulis mengucapkan terima kasih kepada Balai Pelestarian Nilai Budaya Manado yang telah memungkinkan penelitian ini dilaksanakan. Para informan juga mendapat tempat yang istimewa dalam ucapan terima kasih ini karena data, keterangan, kepercayaan dan cerita merekalah yang kami jadikan bahan deskripsi dan analisa dalam artikel ini, teristimewa nenek Arbaya yang telah berpulang beberapa saat setelah kami melaksanakan penelitian dan setelah membilang usia 100 tahun. Ucapan terima kasih yang besar juga kami sampaikan kepada redaksi jurnal AlQalam yang telah memberikan kritik dan berbagai masukan yang memungkinkan artikel ini dapat diterbitkan.

\section{DAFTAR PUSTAKA}

Babcock, Tim G. 1989. Kampung Jawa Tondano; Religion and Cultural Identity. Yogyakarta: Gadjah Mada University Press.

Belo, Jane. 1980. "Lukisan Anak-anak di Bali", dalam Ihromi, T.O. (Ed.) Pokok-pokok Antropologi Budaya. Jakarta: Gramedia. hlm. 180 - 203.

Carey, Peter. 2012. Kuasa Ramalan; Pangeran Diponegoro dan Akhir Tatanan Lama di Jawa, 1785 - 1855. Jakarta: KPG dan KITLV. 2014. Takdir; Riwayat Pangeran Diponegoro (1785 - 1855). Jakarta: Kompas.

Djakaria, Salmin. 2003. "Perkawinan Campuran di Minahasa (Kasus Kampung Jawa Tondano), dalam Jurnal Esagenang Vol. 1 Edisi Februari 2003. BKSNT Manado. hlm. $1-25$.

2008. "Kesenian Hadrah di Kampung Jawa Tondano", dalam Jurnal Esagenang Vol 6 No. 12. BKSNT Manado. hlm. 157-194. 
Penanaman Nilai ke Ekspresi Seni Tari di Gorontalo", dalam Jurnal Esagenang, Vol 11, No 20. BPNB Manado. hlm. $41-55$

Hasan, Chalidjah. 1977. "Kelahiran dan Pengasuhan Anak di Pedesaan Aceh Besar", dalam Alfian (Ed.), Segi-segi Sosial Budaya Masyarakat Aceh; Hasil-hasil Penelitian dengan Metode Grounded Research. Jakarta: LP3ES. hlm. 117 $-142$.

Hatta, Meutia F. Swasono (Ed.) 1998. Kehamilan, Kelahiran, Perawatan Ibu dan Bayi dalam Konteks Budaya. Jakarta: UI Press.

Ihromi, T.O. (Ed.) 1980. Pokok-pokok Antropologi Budaya. Jakarta: Gramedia.

Kementerian Pendidikan dan Kebudayaan RI. 2010. Kebijakan Nasional Pembangunan Karakter Bangsa. Jakarta.

Koentjaraningrat. 2009. Pengantar Ilmu Antropologi. Jakarta: Rineka Cipta

. (Ed.). 1977. Metode-Metode Penelitian Masyarakat. Jakarta Penerbit PT Gramedia.

1977. "Metode Penggunaan Data Pengalaman Individu", dalam, Koentjaraningrat (ed.). Metode-Metode Penelitian Masyarakat. Jakarta Penerbit PT Gramedia, halaman 197 - 214.

Nasution. 1988. Metode Naturalistik Kulitatif. Bandung: Tarsito.

Sandiah, Nasrun. 2002. "Beberapa Aspek Integrasi Sosial di Kampung Jawa Tondano”, dalam
Sandiah, Nasrun dan Alex J. Ulaen (Eds.). Niyaku Toudano; Maulud Tumenggung Sis dan Orang Jaton. Manado: Balai Kajian Sejarah dan Nilai Tradisional Manado dan Laboratorium Jurusan Antropologi FISIP Unsrat

Sandiah, Nasrun dan Alex J. Ulaen (Eds.). 2002. Niyaku Toudano; Maulud Tumenggung Sis dan Orang Jaton. Manado: Balai Kajian Sejarah dan Nilai Tradisional.

Siegel, James T. 1980. "Anak-anak dalam Keluarga", dalam Ihromi, T.O. (Ed.), Pokok-pokok Antropologi Budaya. Jakarta: Gramedia. hlm. $204-215$.

Sulaiman, Haji Syed Abdullah bin Syed, 2000. "Tradisi Lisan: Satu Penilaian Semula". Makalah. tp.

Sutrisno, Mudji dan Hendar Putranto (Eds.) 2005. Teori-teori Kebudayaan. Yogyakarta: Kanisius

Tuloli, Nani. 1990. Tanggomo; Salah Satu Ragam Sastra Lisan Gorontalo. Jakarta: Intermasa

Tumenggung Sis, Maulud. 2002. "Etnik Minoritas Islam Minahasa di Tanah Minahasa" dalam Sandiah \& Ulaen (eds.). Niyaku Toudano; Maulud Tumenggung Sis dan Orang Jaton. Manado: Balai Kajian Sejarah dan Nilai Tradisional. hlm. 37 - 62.

Zuchdi, Damiyati, dkk. 2013. Model Pendidikan Karakter Terintergrasi dalam Pembelajaran dan Pengembangan Kultur Sekolah di Baturetno dan Banguntapan. Laporan Penelitian. Yogyakarta: tp. 